\title{
Tativa
}

JOURNAL OF PHILOSOPHY

\section{GOD-WORLD POLARITY: A PARADIGM FOR RECONCILIATION}

\section{Augustine Thottakara, CMI}

\section{Introduction}

In the first place, let me very cordially and warmly welcome you all, respected delegates of the conference and invited guests, to Dharmaram College. Dharmaram College is the major seminary of our Congregation, the Carmelites of Mary Immaculate (CMI). The word "Dharma-äräm" means garden (äräm) of dharma, and the word "dharma" has a variely meanings like righteousness, religion, law, duty, virtue, morally correct way of life, etc. For us Dharmaram means garden of virtues, and the real garden of virtues and auspicious qualities is the Sacred Heart of Jesus to whose care and protection this seminary and all allied institutions are dedicated to. Secondly, I am very hoppy and feel fortunate and privileged to be part of this great international academic event, the Seventh International Whitehead Conference, with so many eminent scholars from home and abroad. At the same time I also feel sad that the recent horrendous terrorist attacks in Mumbai and elsewhere have frightened away many of the international participants of this seminar.

I am frying here to give expression to an Indian ethos and an Indian interpretation of process philosophy, the architect of which is Alfred North Whitehead, - scientist, mathematician and philosopher - all rolled in one person. Whitehead himself thinks that his thought on process has striking affinity to Indian philosophy. He says, "The philosophy of organism seems to approximate more to some strains of Indian or Chinese thought than to western Asiatic or European thought. ${ }^{\prime 1}$ 


\section{1. 'Process' in the Context}

"Process, Religion and Society" is the theme of this Seventh International Whitehead Conference. Whitehead and Charles Hartshome, the two chief advocates of Process Philosophy and Process Theology, assert that all acluality is dynamic, is process. Process thought categorically rejects static and stagnant actuality. A person, thing or event has to be a process to be really actual, and any object which is not a process connot be characterized as really actual. Such non-process realities would be an idealization or abstraction from process. Whitehead's views on process, it seems to me, are very much similar to the doctrine of momentariness or transitoriness $(k s ̧$ nika-väda) of Buddhists. For Buddhism everything is momentary. Everything is relative. Everything is conditional. Everything is dependent. An object perishes when the condition in which it originated is removed. World and its objects are never permanent. The universe is a constant chain of change: momentary coming into existence and disappearance. Every object comes into existence from an antecedent condition, and gives rise to a consequent object or effect. It is like the flame of the lamp: the flame is actually the continuity of successive flames. A flame exists only a moment, but it gives rise to the next flame. Or, it is like the flow of water in the river. A river is a continuous rapid succession of coming and going of water. The seeming permanence or existence is only a rapid continuity of becoming and disappearance. Whitehead too teaches that all objects are momentary appearances; they come into being and disappear. For him time is not one straight entify without units; time is successive units of moments. There is, however, a very radical and vital difference: Buddhism denies and repudiates the existence and reality of all objects. They are all mental constructs and illusory projections. Process thought would not deny real existence; but upholds that existence changes, and is in process.

Process philosophers have sufficiently deliberated on God and world. The content and dynamics of the concept 'God' for process followers, however, are quite different from the understanding of God-concept in traditional religions. Listen to what process philosopher Cobb Jr., who is with us today, says, "The term is philosophically and religiously opposed to much that has been meant by "God" in metaphysical, theological and popular iraditions". ${ }^{2}$ Process thought rejects five common attributes of God found in world religions. They reject (i) God as Cosmic Moralist, (ii) God as the Unchanging and Passionless Absolute, (iii) God as Controlling Power, (iv) God as Sanctioner of Status Quo, and (v) God as Male. ${ }^{3}$ 


\subsection{The Problem that Calls Our Attention}

There had always been discussions and debates among philosophers, theologians and religious masters on the issue of God-world relationship and related questions like the problem of evil, one and many, life after death, etc. God and world are two opposife poles with seeming incongruencies and incompatibilities between them. God, the absolute and ultimate Reality, is normally conceived as eternal, immutable, immeasurable, unfathomable, omnipotent, etc. Material elemental world on the other hand is limited, measurable, divisible, changeable and destructible. The chasm between the two is unbridgeable. The solution of the Semitic religions to the question of one and many and God-world relationship is simple and straightforward: God, the almighty, created this cosmos out of nothing. The Indian answers to the questions: "What is the relationship between God and world?", or, "How do you explain the issue of one and many?" are very diverse. Ramanuja, a philosopher-saint, who lived in South India in eleventh century (10171137), has seriously deliberated on this issue, and has proposed a paradigm to explain the God-world relationship.

\subsection{The Premises}

Before I reflect on this issue, to have a clear perspective of things, let me call your kind attention to some important premises of Indian religious-philosophical thinking: (i) God, individual selves and matter - these three great principles (tattva-traya) are eternal, that is, without beginning and end. When Hindu scriptures speak of creation and dissolution at beginning and end of each cycle of time, it only means projection or re-presentation of the subtle elements into gross elements and reduction of gross elements into subtle elements respectively. Therefore, creation ex nihilo, out of nothing, and total annihilation of these entities, are not possible. (ii) Consequently, the concept of time and history is for Indians cyclic or spiral, and not linear as in the Semitic cosmology. Time is an indivisible eternal continuum without beginning and end. (iii) The all-pervasive and inexorable law of karma restricts to some extent the sovereignty and omnipotence of God. The destiny of humans depends not so much on God's interventions and grace, but on their own conscious lives and responsible works of the past lives. (iv) Not only human beings, but also animals, plants, trees and, for some schools of thought, even inanimate objects, have souls or self. Human being, therefore, is not a supra-normal or supernatural being incarnated on this earth to conquer, dominate and exploit this earth, but is an integral part of this planet and is intimately related to all the beings of this earth in an unbreakable and inseparable existential bond and is moving towards a common destiny. (v) The understanding of God, world, consciousness, means for liberation, state of liberation, etc. are very diverse in different philosophical systems and religious traditions. 


\section{Cosmos as the Attributive Body of God}

With these words of introduction let me now deliberate on God-world relationship from the perspective of one particular school of Hindu religion and philosophy, namely, the Srivaisnava religion, the philosophy of which is known as Visistadvaita, the Qualified Non-dualism. The founder of this branch of Vedanta is Sri Ramanuja. The concept that cosmos is the attributive body of God was logically developed and philosophically established by this school of Indian philosophy. Ramanuja's greatest contribution to Indian thought is his specific conception and vision of world as God's attributive body and that this awareness and confession and a life suited to this awareness is the means for spiritual perfection and final liberation.

Like the Advaita of Sankara, Ramanuja also proposed that the Reality is only one without a second, the Brahman. But unlike Advaita and against the philosophy of Sankara which projected an impersonal Absolute, Ramanuja declared that this one Reality is qualified, is with attributes and is personal. Brahman or God possesses auspicious qualities like omniscience, omnipotence, love, mercy, etc. Further, this school of thought taught that the other two eternal realities, namely, individual selves (cit) and malter (acit), are modes (prakōra) of Brahman. Both these inseparable modes together are conceived as the body of Brahman. Although the individual selves and matter are true realities, and not illusory as Advaita advocates, they are absolutely dependent on God for their existence and functions and are constantly controlled by God for his own purposes. These two realities may be conceived logically and rationally as independent and separate, but existentially and ontologically they are totally dependent on and inseparable from the ultimate Being, God. It is like the relation between human body and soul. The material body of humans is totally dependent on the inner reality soul for its existence as body and for the bodily funclions. Without the soul or self, the body is dead and valueless. In the same way, Brahman is the Self and inner controller of the individual selves and of the world of matter. This relationship between cosmos and God is known as the 'body-soul relationship' (s'arira-śariri-bhāva). It would be useful here to recall Ramanuja's definition of body: "Any substance which a conscious self is capable of controlling and supporting for its own purpose, and which stands to the conscious self in an entirely subordinate relation, is the body of that conscious self" (Śribhāşya II.1.9).

Could the imperfections, impurities, permutations, limitations and finiteness of this attributive body affect Brahman, which is perfection itself, pure, unchangeable, supreme and infinite? They cannot, because the individual selves and matter form only the attributive body of Brahman and not his real body. The real glorified body 
of Brahman as well as of the liberated selves are made up of suddha-sattva, the efernal, changeless, pure and luminous sattva substance. This real body or form of God is to be explained in terms of non-materiality, transcendence and selfsufficiency. It is this body or divine form that inspires love, admiration and adoration in the hearts of the devotees. The direct experience of God by the mystics is the intuitive and experiential vision of this form of God. It is this form that Arjuna sees in Krsna in Gitō chapter XI, which is a symbolic description of the Lord's body. Ramanuja and other theistic Vaisnava saints are never tired of describing the beauly and splendour of this divine form.

The changes, impurities, etc. of the attribulive body never affect or influence the nature and essence of God, just like the changes and qualities of the human body in childhood, youth, old age, as well as its colour, size, health, etc. never affect the human self. "In the heart of all beings, who constitute My body, I am seated as their Self. To be the Self means that I om entirely their supporter, controller and master" Ramanuja's GitäbhöşyaX.20). Thus theologically speaking this vision of reality in soul-body model and paradigm furnishes a framework which synthesizes and integrates the extreme forms Vedanto, namely, the non-dualism of Sankara and the dualism of Madhva.

\section{Process of Evolution and Involution}

This attributive body of Brahman has two forms, namely, a subtle form and a gross form. In its gross form, this body of Brahman is the effect, that is, the cosmos and every entity in the cosmos that we see and experience. The attributive body of God in its subtle form is the cause. In this causal form, the elements of the universe exist in Brahman in their indivisible and invisible atomic size as his subtle body. The evolution of Brahman's subtle body into his gross body, that is, the cause becoming effect into different names and forms, is called the creation. The dissolution of cosmos is the movement in the reverse order, namely, the gross body of Brahman assumes its subtle state. Therefore, the cosmos, which comprises inanimate matter, animate and conscious beings, in all its states and forms constitutes the body of God.

God is the creator, sustainer and destroyer/saviour (srs $\$$ fi-sthiti-samhara) of the cosmos which is his own attributive body. As far as the individual conscious selves are concerned, who also form part of the attributive or cosmic body of God, there are two types of movements: one is the evolutionary movement, which is the process of creation or re-creation or re-projection. The other is an involutionary movement, which is the return of selves to God in the final and total liberation, which is called the salvation. 
It is at the will of God that his subtle body, the causal elements, evolves into different beings and objects of the world. The Chändogya Upanişad (VI.1 .4.) uses a beautiful simile to explain this creation process. From the one and same lump of clay the potter produces innumerable objects like plates, vases, jugs, pots, etc. But the clay, the essence and material cause of all these objects is the same. Differences are only in names and forms. The products are given distinctive names suited to their forms. In the same way God's attributive body assumes in creation numerous forms and names. But the body is the same. God then allows the individual selves to enter into these objects and animate them. Finally God himself enters into the animated beings as their innermost Self and inner controller. Thus he is the Self of selves and the Self all material objects.

One should not forget here the vital role the doctrine karma plays. The nature, shape and characteristics of the body of an individual self are defermined by his past karmas (actions).

The pilgrimage of the individual self back to God is the involutionary movement. The seeker of perfection by sädhanas (spiritual efforts) purifies his/her mind and sheds all the results of karma, and consequently its contacts with matter and material world. A spiritually mature soul transcends its name and bodily form and unites itself with divine.

\section{The Three Great Principles (tattva-traya)}

The three great eternal principles, as has already been mentioned earlier, are the ultimate Reality (is'vara), the individual selves (cit) and world of matter (acit). How would Ramanuja view these realities?

\subsection{The Vaisnavite Concept of God}

(i) We need to distinguish between the God of philosophy and metaphysics and the God of religions and sacred books. God of philosophy is the ultimate, absolute supreme Being beyond the reach of the intelligent self. He is immutable, self-subsistent and self-existent, and never stands in need of anything outside of himself. Prayers, devotions and love of devotees do not affect him and do not make any change in him. He is not pleased by devotions nor gets angry at wickedness. $\mathrm{He}$ is the unmoved Mover of Aristotle and the Advaitam of Sankara. God of religion on the other hand, is a person, a God of compassion, love and mercy. He is moved by the genuine love and surrender of devotees and protects them through his grace. The devotee expresses his/her relation to this God through love, dedication, prayers and praises. 
(ii) God-concept in Hinduism is very much compromised and restricted by the all powerful law of karmi. The life situations and psycho-somatic conditions of all living beings are decided and defermined by their past karmas. God's role is only that of a supervisor who allows to happen what is the inevitable. Hindu philosophy and religious texts speak of the three cosmic interventions of God in the world, namely, creation, maintenance and destruction/salvation. But these are to be understood in the restricted sense. Creation, for example, as it has already been mentioned earlier, is not out nothing, but is only reprojection, and that too is dictated by the karma of the implied and related lives. The very orthodox system of Mimamsa considers the revelatory part (Sruti) of sacred texts as eternal, authorless, infallible and self-evident (apauruşeya). But this system does not believe in God, a creator-God or a saviour-God. It is atheistic. However, in this system the law of karma, the consequence of which they call apüra, the unseen power, takes the role of God. It is this unseen power that determines the future course of lives.

(iii) Ramanuja teaches that God is the material cause of the universe, because it is his attributive body in its causal subtle state that evolves into effects. God is also the efficient cause, because by his will and power he acts as the agent of creation, which is explained as the evolution of his subtle-causal attributive body into his gross body. God is the inner controller of all, the unifying force of the cosmos, and object of religious worship.

(iv) Another issue that calls our attention is the Hindu understanding of God-soul relationship. The powerful Vedantic tradition declares that liberated individual self is equal to God in everything, except in the three cosmic functions, that is, creation, maintenance and destruction/salvation. This is stated in Vedontasūtra IV.4.17: jagadvyōpōravariam prakarañōd asannihitatvōi ca, "Except in the matter of the activity relating to (the creation, etc. of) the world (the released souls possess all the powers belonging to the Lord, because of (the Lord being) the topic in the contexts (wherein the above activity is referred to) and because also of the remoteness (of the released souls therefrom)".

(v) Ramanuja Vedanta describes the descend of God in five successive levels in the descending order. They are: Para, unmanifested, ultimate and absolute form of existence of God in his eternal abode, who is beyond the reach of limited human intellect. This form is not an accessible object of meditation. The second level of descend is wivha, which is God's manifestation in three personal forms, technically known as Sankarşana, Pradyumna and Aniruddha. They are endowed with the six qualities of God, namely, knowledge, strength, lordship, virility, power and splendour (iñanna-bala-aiśvarya-virya-s'akti-tejas). These manifested forms are objects of meditation of devotees, and take care of 
the three cosmic functions, namely, creation, sustenance and destruction. The third level of God's descend is the ten incarnations (vibhava). To protect dharma and to destroy evil, God takes different forms suited to particular time, place and need, and lives among humans in this world. God is with the world and with the people. In fourth level God lives in each living being as its inner controller and as the indwelling presence (anataryamin). God is the Being of beings and is intimately united with each life. God's presence in sanctified material objecłs made out of wood, stone, metal, etc. (arcāvatāra) is the last level of his descend. God exists in images, statues and symbols and exists where his devotees want him to be, and is accessible to all irrespective of places, seasons, day or night. In this state God is actually dependent on his devotees for his existence and functions.

(vi) As mentioned earlier, the philosophy of Ramanuja is known as Qualified Non-Dualism (Visistadvaita). This philosophy is lived by a religious sect, the Srivaisnavism. Visnu is the ultimate Being for them, who, for these Vaisnavifes, is identical with the absolute Brahman of the Upanisads. Visnu is consubstantially united with Sri, that is, Laksmi; hence the name 'Sri-vaisnavism'. God concept necessarily and essentially contains also femininity in it. The feminine principle is part of the essence of divinity. Male and female principles are inseparable like light and luminosity. When one says ' $V$ isnu', it is to be understood Visnu essentially united with Sri/Laksmi. Unity of the Trinity of Christianity is similar to this concept. That is why the followers of this philosophy and religion address God also as mother.

\subsection{Individual Sentient Self}

(i) Individual selves share several characteristics and attributes with the ultimate Being God. One of them is pratyaktva, which means the capacity to illumine oneself for oneself, manifestation of oneself for oneself. Matter can only manifest itself to others. Self-consciousness, sentiency, selfhood, self-luminosity, doership, enjoyership, etc. are other characteristics of God and selves. Liberated selves are equal to God in knowledge and bliss. It is the inner self of matter, but it is, as it is said earlier, the attributive body of God. It is knower, doer and enjoyer.

(ii) Individual selves are divided into three categories: (a) Those who are in bondage (baddhas), in embodied existence, due to the power of karmic law, and those who endure the cycle of births, deaths and rebirths. (b) Those who were once in bondage, but now are liberated ond enjoys the eternal bliss in the eternal abode (muktas). (c) The category of selves who are efernally with the divine Being. These eternally liberated selves were never under the influence of karma and rebirth. 
(iii) There are two types of movements for the self: one is the evolutionary movement, which is the process of assuming embodied existence again and again by the self according to its past karma. In the state of bondage the self migrates from body to body, and is subjected to the inevitable cycle of births, deaths and rebirths. The other is an involutionary movement, which is the return of self to God in the final and total liberation, which is called the salvation.

(iv) Indian religious traditions and even philosophical schools propose a variety of means or paths for the spiritual pilgnimage of the spiritual aspirant (s $\bar{a} d$ haka) to the ultimate goal (sadhya). These means are technically known as paths (märgas) or spiritual efforts for integration (Yogas), or as concentrated and concerted endeavour (sädhana). Final liberation from this samsāra, from the embodied existence marked with exigencies like bondage, sorrows, births, deaths and rebirths is the goal of all these spiritual paths. Ramanuja and other theistic schools of Vedanta propose loving devotion (bhakti-mārga) as the sure means for liberation. The Epic Rāmōyana, Bhăgavata-purāna, Sändilyo-bhakti-sütra, Närada-bhakti-sũtra, the Gitā, the bhakti-literature of the Alvars, etc. are great fext books of bhakti. Ramanuja, Madhva, Caitanya, Vallabha and other Vedantins could build up a philosophy of devotion and could provide rational explanation for this means of liberation. Kabir, Rai Das, Tulsidas, Mira Bai, Jiva Gosami and others were some great proponents of loving devotion of modern India. The word "bhakti" is derived from the verbal root bhaj, meaning to serve, love, worship, to unite, etc. Therefore, the concept of bhakticontains a collective sense of loving devotion, selfless senvice and intimate union. These are the sentiments and also the course of action of those spiritual aspirants who tread the path of loving devotion.

(v) In the scheme of the path of loving devotion, God's grace plays vital role. Pleased with the love, devotion and worship of the devotee, God comes to his/her help and saves him/her. In fact, it is this bhakfi-movement which introduced the concept and dynamics of grace of God in the spiritual and religious scenario of Hinduism. Spirifuality of the Upanisads, Samkhya, Yoga, Nyaya, Vaisesika, Mimamsa, etc. never considered God and his grace as necessary aids for the progress in the spiritual life and for the eschatological good of humans. Each seeker should work out his/her salvation by his/her efforts, by controlling the body senses and mind, by checking the passions and evil hankerings. Bhakti movement however, advocates that God's help is essential for spiritual perfection. Gitö is a powerful example for this. "I shall liberate you from all sins; do not grieve" (XVIII.66), texts like this amply show that God is accessible to all and is capable and willing to help those who take refuge in him. 
(vi) There is however, it seems to me, a slight and subfle difference between the Christian understanding of grace and its bhakti understanding. Christian spirituality feaches that grace of God is a free gift, without any merit of the recipient. Humans have, of course, the responsibility to cooperate with the grace of God and grow in charity. According to Hinduism this grace is already within the human beings. It is now concealed, suppressed and made inoperative by the power of karma, bondage and ignorance. God helps his devotees to rediscover this hidden power and make if work for spiritual growth.

\subsection{Process of Evolution of the Psychosomatic World Order}

(i) Matter, the elemental world, is the third eternal principle. Matter exists in diverse forms and under different names. Unlike the other fwo principles, namely, God and soul, matter undergoes changes and is subjected to evolutionary process. It is to be noted that the intellectual-psychic faculties too are included in this process of evolution. Mind and intellect are formless matter (ajadam dravyam).

(ii) Two systems of philosophy which seriously deliberated on this evolutionary nature of matter are Vaisesika of Kanada (200 BCE) and Samkhya of Kapila (600 BCE). Vaisesika, philosophy of nature, proposes seven basic categories, namely, substance, quality, action, generality (universals), particularity, inherence (relation) and non-existence. Each of these has subdivisions. Ramanuja Vedanta rejects categories like generality, inherence and nonexistence.

(iii) Samkhyan scheme of evolution of psycho-physical world order is more comprehensive and logical, and that is what Visistadvaita accepts as nomative, of course, with necessary changes to suit to its basic worldview. Ramanuja stoutly rejects the metaphysical premises of Samkhya, namely, the dualism. Samkhya professes a realistic dualism, and is atheistic. The two eternal, independent and ultimate principles are purusa (conscious self) and prakr $t i$ (primeval matter). This primordial matter evolves into twenty-three objects of this world, which include also the psychic faculties. Evolutes start with the unmanifested and undifferentiated cosmic intelligence (mahat) and end with the five gross elements. For Samkhya, being atheistic, this evolutionary process is triggered by the presence of the conscious purusa, a passive, non-active, subjective and pluralistic principle. For Romanuja God in the role of efficient cause wills and allows this process. Of course, the all-pervasive karma is operative in generative and transformative course of evolution. We need to remember here the basic thesis of Ramanuja that all these manifestations of primeval matter together with the conscious selves form body of God. 


\section{Dependent-Independent Dynamics}

Some perceived humans and world as tofally different and independent from God. Some others ascertained a non-differential relationship between God and universe; God and self are one and the same; they are identical. Because of our innate and deep-rooted ignorance we perceive them in this phenomenal existence os different. Ramanuja struck a middle path and advocated, as has already been explained earlier, a 'dependent-independent-relation' of the universe to God. Individual selves and world of matter are totally and radically dependent on God for their existence, functions and eschatological goals. But they are also logically and theoretically different from God and have separate individuality. This world-view provides, according to Ramanuja, a rational, reasonable and a theologically sound model to opprehend the supreme Reality and our existence in the world as psychophysical beings and our eschatological goal. The meaning, dignity and destiny of nature and all entities of nature are also eminently safeguarded.

\section{The Macrocosm and the Microcosm}

The Taittiniya Upanişad chapters II and III explain the pilgrimage of the soul to the goal of its existence in a beautiful metaphoric model. The cosmos which is the attributive body of God has four concentric sheaths or encasements (kos'as). The outermost sheath is that of inert, imperfect, changeable and non-conscious matter (annamaya). The second sheath is that of life (pronnamaya). All that has life, starting from the vegetative life, are included in this. These two sheaths are composed of two material elements, namely, earth and air. The third sheath is that of senses and mind (manomaya). All the animal life belongs to this sheath/category. The next sheath is that of consciousness and intelligence. Human beings, the apex of creation, belong to this category. God, the Supreme Being, is on the top of all these, who is identified in this concentric model as the supreme pure Bliss (ānandamaya). A spiritual aspirant has, by force and due to the exigencies of bodily life, to use these sheaths in his embodied existence; but for sake of the total liberation he has to transcend them also. We may call it an inclusive transcendence.

The cosmos, which is made up of matter, life, senses and intelligence is the macrocosm. At the very bottom is the inent, changeable and non-conscious matter. Then comes the world of life. All vegetation, fauna and flora are accommodated in this sphere. The next stratum is subtler and consists of life with senses and mind. The kingdom of animals and birds belongs to this domain. Over and above this come the consciousness and intelligence, the homo sapiens. The supreme Lord, the source and goal of all beings, is on the top of all and controls and dominates all other lower contingent entities. 
Human is the microcosm. Human being too is a harmonious combination of all these sheaths. In his/her embodied existence, he/she is composed of matter, life, senses and mind and consciousness and self. And in the centre of humans, in their innermost self, resides God as his inner controller (antaryämin). Therefore, the structure of human person, the microcosm, corresponds exactly to the structure of the cosmos, the macrocosm. The Indian thinkers went further and said that each part and each member of human body has corresponding entities or realifies in the cosmos. Thus the breath of humans corresponds to the element wind; the flesh, bone and marrow corresponds to the element earth; the blood in human body corresponds to the element water; the eyes to sun and moon; the ears to the ether; the blood vessels to rivers; the hairs on the body to herbs and trees, etc. This paradigm of creation and explanation of the universe is related, and perhaps also indebted, to the Puruşansükta of Rg VedaX.90. One fourth of the efernal Purusa becomes an incarnated Purusa, who is sacrificed by gods for the sake of creation. From this sacrificial act the universe was created. The breath of the sacrificed Purusa becomes the wind, his eyes become sun and moon, his blood becomes rivers, his belly the earth, back the firmament, etc.

This in short is the vision of reality proposed by the Qualified Non-dualism and by Ramanuja its philosopher-founder and saint. However, the conception of universe as God's body is not Ramanuja's invention. Br hadōranyaka Upanişad III.7. narrates a debate between Yainavalkya, the most eminent philosopher of that era, and another Upanisadic seer named Uddalaka, the son of Aruna. Uddalaka asked Yajnavalkya about the inner controller of all beings. Yajnovalkya replied by enumerating a long list of things and said that Brahman is the inner controller of all and that all these things form the body of Brahman. He begins with the earth and said: "He who dwells in the earth and is within it, but whom the earth does not know, whose body is the earth and who controls the earth from within, $\mathrm{He}$ is the inner Controller; $\mathrm{He}$ is your Self, the Immortal". ${ }^{4}$ The philosopher then repeats this sentence and says that God is the inner Controller and inner Self of water, fire, mid-space, air, heaven, sun, all the directions, moon and stars, ether, darkness, light, all beings, vital breath, speech, eye, ear, mind, skin, intellect and semen. Yainavalkya concludes his long discourse with the following statement: "He is never seen, but is the seer; $\mathrm{He}$ is never heard, but is the Hearer; $\mathrm{He}$ is never thought of, but is the Thinker; He is not known, but is the Knower. There is no other hearer than $\mathrm{He}$, there is no other thinker than $\mathrm{He}$, there is no other knower than $\mathrm{He}$. He is the inner controller - your own Self and the Immortal. Every thing else besides him is sorrowful" (BrUp III.7.22). In short Yajnavalkyo was saying that all the great elements by which the universe is constituted, all the sense organs of knowledge, all the organs of activity, and finally all the individual selves, all these things, form the body of God. God is the inner Self of everything, beginning from 
the non-conscious, changeable matter and ending in the conscious, immutable individual selves.

I am tempted to quote a beautiful passage from Mahabharata, the great Epic poem of India:

The father of all creatures, God, made the sky. From the sky he made water and from water he made fire and air. From fire and air the earth came into existence. Mountains are his bones, earth is the flesh, sea is the blood, and sky is his abdomen. Air is his breath, fire is his splendour, and rivers are nerves. The sun and moon which are called Agni and Soma, are the eyes of Brahman. The upper part of the sky is his head. The earth is his feet and directions (disa) are the hands. ${ }^{5}$

Ramanuja's predecessor and teacher Yamunacarya proposed this body-relation between world and God as a reasonable and balanced world view and a sound theological framework to situate a spiritual seeker in his pilgrimage to the ultimate goal of his life. Ramanuja took up this line of theological thought and developed it into a solid system of Indian philosophy and into a very popular branch of Vaisnava religion.

The spiritual path advised by Ramanuja and his school of Vedanta for liberation also is based on this fundamental understanding of God. Ramanuja said that the basic awareness and acceptance of the fact that one is part of God's body, and therefore is radically dependent on him, is the beginning of real spiritual life. It is the key to the doors of total liberation. His vision of cosmos as God's body is not just a means for a philosophical or metaphysical or ontological understanding of the structure of the cosmos. It is above all the motive force for the sadhana, the spintual means, for liberation. Body-soul doctrine should not be reduced to a mere cosmological metaphor or an allegorical way of explaining the dependence of the universe on God. For Ramanuja it is very much real.

All philosophers have tried to unveil the mystery human existence, existence of the world and the ultimate destiny of all these. Some perceived man and world as totally different and independent from God. Some others ascertained a nondifferential relationship between God and universe. Ramanuja struck a middle path and advocated, as has already been explained earlier, a 'dependentindependent-relation' of the universe to God. This world-view provides, according to Ramanuja, a rational, reasonable and a theologically sound model to apprehend the supreme Reality and our existence in the world as spiritual-psycho-physical beings and our eschatological goal. The meaning, dignity and destiny of nature and all entifies of nature are also eminently safeguarded. 


\section{Philosophical-Spiritual Implications of Body-Soul Paradigm}

\subsection{Reconciliation of Dualities}

There is a kind of dualism in all spiritualities and religions, be if Eastern or Western; dualism not in the sense of philosophy, but in the sense of two polarities, or two opposites. This world and the other world, body and soul, human and divine, secular and sacred, profane and holy, matter and spirit, etc. If you want to secure the other world, renounce this world; if you want to save your soul, suppress your body; if you want to become divine, say 'no' to the human, if you want ameliorate your spirit, chastise the matter, etc. 'Integration' is the mantra today. This world is not bad; body is nof evil; matter is not iniquitous; to be really human is to be also divine. The world-denying, happiness-negating, matter-eschewing spirituality is passé. An integrated, holistic vision of this world, life and spirituality is called for. Ramanuja's vision of world as God's body eminently brings about this integration of the divine and mundane.

\subsection{One Organic Whole}

We form part of the divine body, and therefore, we are strictly related to every animate and inanimate objects of this cosmos, even to a speck of dust. All these form one organic whole, the attributive body of God. We are responsible for the well-being of the body, namely, of the earth. It is true that, like most of the classical philosophers and theologians of Hinduism, Ramanuja does not speak in terms of social responsibility and our obligation to our fellow human beings, but he is suggesting that knowing Brahman as our inner Self and as the Self of all beings involves seeing the world's unity in terms of his body. This entails a deeper unity not only with humanity, but also with all creation. A person who knows Brahman and his nature of existence, cannot, therefore, harm a living thing, or do violence to elemental nature. Cosmos is not only the locus where humans live, but they are part of this cosmos. Individual selves and world are ontological extension of God. Body of God is understood in terms of relations, relation between God, conscious and non-conscious beings.

\section{3. 'You are Happy, I am Happy'}

This relatedness has further theological and spiritual implications. Unless and until every member of this body, every life, including the life of plants and trees is happy, my own happiness is incomplete. I am responsible for the well-being of all the 
things in the universe, including the elements. Unless and until every being is liberated my own liberation lacks its fullness. If any member in this body suffers, be it animate or inanimate, it is also my own suffering.

Our personal sanctity is intimately related to our cosmic responsibility. God demands from us holiness of life by purifying our mind and heart of all impurities and by the diligent use of the spiritual paths or sādhanas (spiritual efforts). But this has to take place in a cosmic context. Therefore, personal sanctily and cosmic responsibility go hand in hand.

\subsection{The Spiritual Pilgrimage}

The consciousness of being the body of God is the saddhana (spiritual means) for liberation. Taking inspirations from the sacred scriptures of Hinduism, Rámanuja developed this Body of God-symbolism as the starting point of all human efforts for spiritual perfection and as a tool for God-realization. Bhakti-yoga, the path of loving devotion to God, is for Ramanuja ultimately the knowledge of the divine. For Ramanuja the path of knowledge denotes the knowledge of one's own self and its nature (atmaiñana) and this knowledge consists in the radical awareness that one is a mode of Brahmon and therefore, totally and irrevocably dependent on him. This is the starting point of Bhakti, which should ultimately lead the seeker to the highest form of knowledge, namely, the direct, infuitive, experiential knowledge of the divine form in liberation. We may compare these to the apară and para vidyōs, the lower and higher knowledges, of Muns sdaka Upanisad. Apara vidy $\bar{a}$, the lower wisdom is the knowledge of the fact one is part of the attributive body of Brahman, and parō vidyō is the direct perception of the real body of Brahman in the state of eternal liberation.

\section{Conclusion}

I would like to conclude this presentation with a prayer for peace. India, our motherland, is in the grip of aśantih and unwholesome conditions. Parts of God's body are in pain and agony. The peace chant of Śukla Yajurveda (ca. 1200 BCE) runs like this:

Om sāntir, amtarikş̧ām śāntih, p̣̣thivi śōntir /

ōpah śāntir, oşadhayah šāntir, vanaspatayah śōntih /

viśvedevāh śāntih, brahma šāntih, sarvam soōntih /

śāntir eva śōntih, sãma śāntir edhi // Om śāntih śāntih sōntih // 
Om peace. May there be peace unto heaven, unto the sky let there be peace, unto the earth may there be peace, peace unto the waters, peace unto the herbs and trees. May there be peace unto all the gods and unto the Brahman may there be peace, may there be peace unto all beings. Peace verily the peace. May that peace also come to me. Om peace, peace, peace" (Śukla Yajurveda, XXXVI.17).

\section{Notes:}

1. Quoted in the Conference brochure from Whitehead's Process and Reality, p. 7. Whilehead characterizes his philosophy also as 'Philosophy of Organism'.

2. John B. Cobb, Jr. and Dovid Ray Griffin, Process Theology. An Iniroductory Exposition, (Philodelphio: The Westminster Press, 1976), p.14.

3. $\quad$ bid, pp. 8-9.

4. Brh. Up lll.7.3: yah prthivām lişhan prthivya antarah yam prthivi na veda yasya prthivi sariram yoh prthivim antoro yamayali eşa la almāntryāmy amı́tah //

5. In the following section of the Brhadaranyaka Upanisad (ill.8.3.12) Yajnavalkya answering a question of Gargi states that this God pervades everything in the universe.

6. Mahabhōrala, Makșadharmaparva, 182.14-19 in O.P. Dwivedi \& B.N.Tiwari, Environménlal Crisis and Hindu Religion, (New Delhi: Gitanjali Publishing House, 1987), p. 126. 